\title{
PENGARUH PENGELOLAAN KELAS GURU BAHASA INDONESIA TERHADAP MOTIVASI DAN PRESTASI BELAJAR BAHASA INDONESIA SISWA KELAS VIII SMP NEGERI 2 TAMBAK-BANYUMAS
}

\author{
Sudrajat Dwi Prihanto ${ }^{1}$, Santhy Hawanti ${ }^{2}$ \\ ${ }^{1}$ SMP Negeri 2 Tambak, Kabupaten Banyumas \\ ${ }^{2}$ Univeristas Muhammadiyah Purwokerto
}

Email: dwi.drajat01@gmail.com, santhyhawanti.ump@gmail.com

\begin{abstract}
Abstrak
Tujuan penelitian adalah: 1) mendeskripsikan persepsi siswa terhadap pengelolaan kelas oleh guru; 2) mendeskripsikan motivasi belajar siswa; 3) menyajikan data besarnya nilai rata-rata prestasi belajar Mapel Bahasa Indonesia; 4) menganalisis pengaruh pengelolaan kelas oleh guru terhadap motivasi belajar siswa; 5) menganalisis pengaruh pengelolaan kelas oleh guru terhadap prestasi belajar siswa; dan 6) membuktikan mana yang lebih terpengaruh dari pengelolaan kelas, motivasi belajar atau prestasi belajar siswa. Jenis penelitian adalah kuantitatif dengan pendekatan korelasional. Subjek penelitian seluruh siswa kelas VIII sebanyak 187 anak dengan sampel 30\% sehingga diperoleh sampel 57 anak dengan teknik proporsional random sampling. Metode pengumpulan data digunakan angket dan dokumentasi berupa daftar nilai dari prestasi belajar mata pelajaran Bahasa Indonesia. Adapun teknik analisis data digunakan analisis deskriptif persentase dan regresi linier berganda. Hasil penelitian diperoleh simpulan: 1) persepsi siswa terhadap pengelolaan kelas diperoleh skor 52,72\% dengan kriteria setuju; 2) persepsi siswa terhadap motivasi belajar diperoleh skor 52,72\% dengan kriteria setuju; 3) prestasi belajar Mapel Bahasa Indonesia diperoleh nilai rata-rata 84,84 dengan kriteria baik; 4) terdapat pengaruh positif dan signifikan pengelolaan kelas guru terhadap motivasi belajar siswa dengan nilai koefisien 0,326 atau 32,6\%, ini berarti sisanya 67,4\% dipengaruhi oleh faktor lain selain variabel yang digunakan penelitian ini; 5) terdapat pengaruh positif dan signifikan pengeloaan kelas oleh guru terhadap prestasi belajar siswa dengan nilai koefisien 0,314 atau 31,4\%, ini berarti sisanya 68,6\% dipengaruhi oleh faktor lain selain variabel yang digunakan penelitian ini; dan 6) variabel yang terpengaruh lebih besar dari pengelolaan kelas guru adalah variabel motivasi belajar siswa, karena diperoleh skor 0,326 > 0,314 dari pengaruh pengelolaan kelas terhadap prestasi belajar siswa.
\end{abstract}

Kata kunci: pengelolaan kelas, motivasi, prestasi belajar

\begin{abstract}
The research objectives were: 1) to describe students' perceptions of classroom management by teachers; 2) describe students' learning motivation; 3) presents data on the average value of learning achievement Mapel Bahasa Indonesia; 4) to analyze the effect of classroom management by teachers on student motivation; 5) to analyze the effect of classroom management by teachers on student achievement; and 6) prove which one is more affected by class management, learning motivation or student achievement. This type of research is quantitative with a correlational approach. The research subjects were all students of class VIII as many as 187 children with a sample of $30 \%$ in order to obtain a sample of 57 children with proportional random sampling technique. Data collection methods used questionnaires and documentation the form of a list of values from learning achievement in Indonesian
\end{abstract}


subjects. The data analysis technique used percentage descriptive analysis and multiple linear regression. The results obtained conclusions: 1) students' perceptions of class management obtained a score of $52.72 \%$ with agreed criteria; 2) students' perceptions of learning motivation obtained a score of $52.72 \%$ with agreed criteria; 3) the learning achievement of Indonesian Language Subjects obtained an average value of 84.84 with good criteria; 4) there is a positive and significant effect of teacher classroom management on student learning motivation with a coefficient of 0.326 or $32.6 \%$, this means that the remaining $67.4 \%$ is influenced by other factors besides the variables used in this study; 5) there is a positive and significant effect of classroom management by teachers on student achievement with a coefficient value of 0.314 or $31.4 \%$, this means that the remaining $68.6 \%$ is influenced by factors other than the variables used in this study; and 6) the variable that is more affected by the management of the teacher's classroom is the variable of student learning motivation, because the score is 0.326>0.314 from the effect of classroom management on student achievement.

Keywords: class management, motivation, learning achievement

\section{PENDAHULUAN}

Kualitas pendidikan akan tercapai bila proses pembelajaran yang diselenggarakan di kelas efektif dan berguna untuk mencapai kemampuan pengetahuan, sikap, dan keterampilan yang diharapkan pada diri siswa. Hal itu dapat terjadi, sebab pelaksanaan pembelajaran oleh guru merupakan inti dari proses pendidikan secara keseluruhan di sekolah. Guru merupakan salah satu faktor penting dalam menentukan keberhasilan proses pembelajaran di kelas. Oleh karena itu guru dituntut untuk meningkatkan peran dan kompetensinya guna menciptakan lingkungan belajar yang efektif dan memiliki kemampuan pengelolaan kelas yang terwujud dalam proses pembelajaran.

Proses pembelajaran merupakan operasionalisasi perencanaan pengajaran, maka tidak dapat lepas dari perencanaan pengajaran yang telah disusun oleh guru. Kondisi tersebut berarti bahwa dalam pelaksanaannya sangat tergantung pada perencanaan pengajaran sebagai operasionalisasi dari sebuah kurikulum yang dilakukan guru, sehingga pengelolaan kelas sangat penting dilaksanakan guru.
Guru sebagai komponen dalam proses pembelajaran ikut berperan dalam usaha membentuk SDM yang potensial di bidang pembangunan. Oleh karena itu, guru sebagai salah satu unsur bidang pendidikan harus berperan aktif dan menempatkan kedudukannya sebagai guru profesional. Singkatnya, pada diri setiap guru terletak tanggung jawab untuk membawa para siswa pada suatu arah kedewasaan dan taraf kematangan tertentu. Pada kondisi ini guru tidak hanya sebagai "pengajar", tetapi juga sebagai "pendidik" dan sekaligus sebagai "pembimbing" (Sardiman, 2012). Berkaitan dengan hal itu, guru memiliki peran unik dan kompleks dalam usaha mengantarkan para siswa atau peserta didik ke taraf yang dicita-citakan. Oleh karenanya setiap rencana dan kegiatan yang dilakukan guru harus ditujukan demi kepentingan siswa sesuai dengan profesi dan tanggung jawabnya.

Selain sebagai pengajar, pendidik, dan pembimbing, guru juga harus dapat menempatnkan dirinya sebagai manajaer. Peran guru sebagai manajer dalam kegiatan belajar di kelas, bahkan sudah lama diakui sebagai salah satu faktor penting dalam meningkatkan prestasi belajar pada siswa. Guru profesional 
mampu mengelola pembelajaran dan mengelola kelas dengan baik, guna menciptakan dan mempertahankan kondisi belajar optimal demi tercapainya tujuan belajar.

Pengelolaan kelas merupakan salah satu solusi guna pemecahan masalah yang mendasar dari persoalan pendidikan di tanah air. Kepentingan tersebut guru harus mampu menjalankan perannya sebagai demonstrator, pengelola kelas, mediator dan fasilitator, serta evaluator dengan semaksimal mungkin sebab kepentingan tersebut menjadi dasar keberhasilan dalam proses pembelajaran yang berkualitas.

Secara psikologis guru harus memperhatikan kepribadian dan karakter anak serta disesuaikan dengan lingkungan, baik ekonomi, sosial, dan sebagainya serta pesan-pesan dari kurikulum perencanaan pembelajaran dan pengeloaan kelas. Semua aspek tersebut akan tergambarkan dalam bagian pembelajaran atau skenario pembelajaran yang dilakukan oleh guru yang ditujukan kepada peserta didik (Mudzakir, 2012).

Berkaitan dengan pembelajaran, hal yang tidak dapat terpisahkan darinya adalah pengelolaan kelas. Pembelajaran sebagai suatu kegiatan yang melibatkan seseorang dalam upaya memperoleh pengetahuan, keterampilan dan nilai-nilai positif dengan memanfaatkan berbagai sumber untuk belajar. Pembelajaran dapat melibatkan 2 (dua) pihak yaitu peserta didik sebagai pembelajar dan guru sebagai fasilitator. Hal terpenting dalam kegiatan pembelajaran adalah terjadinya proses belajar (learning process). Proses pembelajaran itu terdapat pesan-pesan yang harus dikomunikasikan. Pesan tersebut juga merupakan isi dari suatu topik pembelajaran. Pesan-pesan disampaikan oleh guru kepada peserta didik melalui suatu media dengan menggunakan prosedur pembelajaran tertentu yang disebut metode (Nasution, 2011). Dikemukkan lebih lanjut pembelajaran dikatakan sebagai sistem, karena di dalamnya mengandung komponen yang saling berkaitan untuk mencapai tujuan yang telah ditetapkan. Komponenkomponen tersebut meliputi: tujuan, materi, metode, media, dan evaluasi (Sinduwinata, 2012). Oleh karena itu usaha untuk menunjang pencapaian tujuan pembelajaran dibantu dengan penggunaan alat pembelajaran yang tepat dan sesuai dengan karakteristik komponen penggunaannya, seperti halnya media Teknologi Informatika (TI) yang seharusnya juga dilaksanakan di SMP Negeri 2 Tambak.

Proses pembelajaran di SMP menekankan ilmu dasar sebagai sebuah teori untuk dipraktikkan ke dalam kehidupan sehari-hari. Oleh sebab itu materi pempelajaran dipenuhi dengan nilainilai bagi pembentukan pribadi dan karakter anak, sehingga jika materi disajikan dengan cara kurang tepat, maka dapat menimbulkan rasa tidak senang pada siswa terhadap pelajaran, bahkan kepada guru dan yang lebih mengkhawatirkan lagi adalah anak tidak memiliki motivasi untuk belajar sehingga belajar akan gagal (Davis, 2012).

Guru memiliki peran penting dalam menentukan kualitas yang dilaksanakan dalam proses pembelajaran. Guna memenuhi kualitas tersebut, guru dituntut untuk mampu mengelola kelas dalam proses pembelajaran yang memberikan rangsangan atau stimulus kepada anak sehingga anak memiliki motivasi belajar secara optimal (Usman, 2010).

Dikemukakan lebih lanjut bahwa motivasi juga dapat dijabarkan sebagai tujuan yang ingin dicapai melalui belajar. Konsep ini siswa berusaha mencapai tujuan karena dirangsang oleh manfaat atau keuntungan yang akan diperoleh. Motivasi siswa tercermin melalui ketekunan yang tidak mudah patah untuk mencapai sukses, meskipun dihadang berbagai kesulitan. Hal ini seperti dikemukakan Maksum (2011); manfaat motivasi belajar bagi siswa dan guru pada 
suatu lembaga pendidikan adalah: 1) menyadarkan kedudukan belajar, proses, dan hasil akhir; 2) memberi informasi kekuatan usaha belajar; 3) mendongkrak semangat belajar siswa; dan 4) mengarahkan kegiatan belajar sebagai ilustrasi, setelah ia ketahui bahwa dirinya belum belajar secara serius.

Penjelasan di atas menunjukkan bahwa motivasi belajar memberikan manfaat besar dalam menyadarkan kegiatan belajar siswa, menginformasikan dan mengarah kegiatan belajar. Hal tersebut akan dapat membawa dampak positif terhadap pendidikan siswa dalam meraih prestasi belajar. Motivasi belajar juga penting diketahui bagi guru guna mendalami pengetahuan dan pemahaman tentang motif yang dimiliki siswa dalam belajar. Hal tersebut senada dengan pemikiran Simamora (2010) yang menyatakan bahwa motivasi selain bermanafaat bagi siswa juga bermanfaat bagi guru, yaitu: 1) membangkitkan dan memelihara semangat siswa untuk belajar sampai berhasil; dan 2) meningkatkan dan menyadarkan guru untuk memilih salah satu diantara bermacam-macam peran, baik sebagai penasehat, fasilitator, instruktur, teman diskusi, penyemangat, maupun guru sebagai pendidik. Oleh sebab itu, motivasi memiliki manfaat timbal balik kepada guru dan siswa. Motivasi merupakan pendorong semangat bagi guru dan bagi siswa dalam meraih tujuan pendidikan. Dengan demikian motivasi memiliki kaitan erat dengan tujuan yang akan dicapai, yaitu tujuan pembelajaran yang berujung pada pencapaian prestasi belajar secara maksimal oleh siswa. Motivasi bagi siswa juga dapat mengembangkan aktifitas dan inisiatifnya, selain dapat mengarahkan dan memelihara ketekunan dalam melakukan kegiatan belajar bagi dirinya.

Disadari atau tidak dalam menentukan tujuan belajar perlu berbuat dalam bentuk kegiatan tertentu, sedangkan dalam berbuat diperlukan motivasi sebagai daya gerak atau pendorong. Motivasi sebagai daya dorong dapat juga ditanamkan kepada diri siswa dengan cara memberikan latihan-latihan atau kebiasaan-kebiasaan yang kadang juga dipengaruhi oleh lingkungan. Oleh sebab itu dalam kegiatan pembelajaran, peran motivasi sangat diperlukan.

Paparan di atas senada dengan hasil penelitian Bakar (2014) dengan judul: "Pengaruh Motivasi belajar terhadap Kompetensi Keahlian Siswa". Hasil penelitian diperoleh simpulan secara deskriptif bahwa motivasi belajar siswa termasuk kriteria sangat baik, kompetensi keahlian yang dipilih oleh siswa juga termasuk kriteria sangat baik, serta ada pengaruh positif dan signifikan motivasi belajar terhadap kompetensi keahli-an produksi yang dipilih oleh siswa SMK Negeri di Sumatera Barat. Penelitian selanjutnya dilakukan oleh Koutrouba (2018): "Gaya pengelolaan kelas: sebuah persepsi guru di Yunani. Hasil penelitian menunjukkan bahwa ada 2 (dua) dimensi dalam pengelolaan kelas, yaitu dimensi manajemen instruksional dan manajemen perilaku dengan berbagai indikator yang mengupasnya. Sedangkan manajemen pembelajaran mengacu pada: 1) upaya guru untuk merencanakan dan melaksanakan rutinitas pengajaran sehari-hari; 2) Merancang kegiatan belajar untuk siswa; 3) memilih bahan pembelajaran; dan 4) memantau dan menilai prosedur belajar dan kinerja akademik siswa dalam lingkungan belajar yang konstruktif. Adapun manajemen perilaku mengacu pada: 1) penetapan aturan yang menghalangi siswa untuk menampilkan perilaku buruk; 2) memberi penghargaan kepada siswa untuk perilaku positif; dan 3) memotivasi siswa untuk menerima serta memanfaatkan sepenuhnya aturan sekolah. Secara keseluruhan diperoleh kriteria sangat tinggi sehingga ke depan dapat 
dijadikan sebagai acuan pada penelitian dengan dimodifikasi variabel lain.

Berdasarkan uraian di atas dapat dikemukkan bahwa motivasi yang kuat sangat diperlukan dalam belajar, sedangkan dalam membentuk motivasi yang kuat tersebut dapat dilakukan dengan latihanlatihan atau kebiasaan-kebiasaan melalui proses pembelajaran. Oleh sebab itu dalam mencapai prestasi belajar secara optimal diperlukan adanya motivasi, hal ini sebagai akibat dari kemampuan guru dalam pengelolaan kelas melalui proses pembelajaran, termasuk yang dilakukan oleh guru dalam mata pelajaran Bahasa Indonesia. Dengan demikian rumusan masalah penelitian ini terkait dengan pertanyaan: 1) persepsi siswa terhadap pengelolaan kelas oleh guru; 2) motivasi belajar yang dimiliki oleh siswa; 3) besarnya prestasi belajar siswa pada Mapel Bahasa Indonesia; 4) pengaruh pengeloaan kelas guru terhadap motivasi belajar siswa; 5) pengaruh pengeloaan kelas guru terhadap prestasi belajar siswa; dan 3) mana yang lebih terpengaruh oleh pengelolaan kelas guru, motivasi belajar atau prestasi belajar siswa, bagaimana dapat terjadi.

\section{METODOLOGI}

Jenis penelitian termasuk kuantitatif dengan pendekatan korelasional (Arikunto, 2012). Subjek penelitian seluruh siswa kelas VIII yang berjumlah 187 anak dengan sampel 30\% sehingga diperoleh sampel 57 anak dengan proporsional random sampling. Teknik pengumpulan data digunakan angket dan dokumentasi berupa daftar nilai dari prestasi belajar Mapel Bahasa Indonesia, yaitu nilai ulangan harian, nilai ujian tengah semester, dan nilai ujian akhir semester setelah dijumlah dan dicari rata-ratanya.

Sebelum alat pengumpul data utama berupa instrumen angket digunakan untuk memperoleh data di lapangan yang diberikan kepada 57 siswa, terlebih dahulu dilakukan uji validitas dan reliabilitas kepada 10 siswa. Kesepuluh siswa tersebut termasuk dalam populasi, tetapi kedudukannya bukan sebagai sampel. Dari ke21 item angket pengelolaan kelas dan ke24 item angket motivasi belajar kelas semua termasuk kriteria valid dan reliabel, karena $r_{\text {hitung }}>r_{\text {tabel }}=0,05$ (Setiaji, 2012), kecuali untuk prestasi belajar tidak dilakukan perhitungan validitas dan reliabilitas karena nilai sudah berbentuk matang atau nilai jadi dari dokumen sekolah. Adapun teknik analisis data digunakan analisis deskriptif persentase dan regresi linier berganda (Ghozali, 2012).

\section{HASIL DAN PEMBAHASAN}

Secara keseluruhan hasil penelitian yang dilakukan kepada seluruh responden sebanyak 57 siswa dapat direkap dan disajikan seperti pada tabel berikut.

\begin{tabular}{llll}
\multicolumn{4}{c}{ Tabel 1: Hasil Analisis Deskriptif } \\
\hline No & $\begin{array}{l}\text { Analisis } \\
\text { Deskriptif }\end{array}$ & Hasil & Kriteria \\
\hline 1 & $\begin{array}{l}\text { Persepsi siswa } \\
\text { terhadap } \\
\text { pengelolaan kelas } \\
\text { guru. }\end{array}$ & $52,72 \%$ & Setuju \\
2 & & \\
$\begin{array}{l}\text { Persepsi siswa } \\
\text { terhadap motivasi } \\
\text { belajar. }\end{array}$ & $57,95 \%$ & Setuju \\
3 & $\begin{array}{l}\text { Prestasi belajar } \\
\text { siswa Mapel Bahasa } \\
\text { Indonesia }\end{array}$ & 84,84 & Baik \\
\hline
\end{tabular}


Tabel 2: Koefisien Pengaruh X terhadap Y1 dan Y2

Coefficients $^{\mathrm{a}}$

\begin{tabular}{|c|c|c|c|c|c|}
\hline \multirow[b]{2}{*}{ Model } & \multicolumn{2}{|c|}{$\begin{array}{l}\text { Unstandardized } \\
\text { Coefficients }\end{array}$} & \multirow{2}{*}{$\begin{array}{c}\text { Stand } \\
\text { ardize } \\
\mathrm{d} \\
\text { Coeffi } \\
\text { cients } \\
\text { Beta }\end{array}$} & \multirow[b]{2}{*}{$\mathrm{t}$} & \multirow[b]{2}{*}{ Sig. } \\
\hline & B & $\begin{array}{l}\text { Std. } \\
\text { Error }\end{array}$ & & & \\
\hline 1 (Constant) & 51.12 & 10.29 & & & .000 \\
\hline Motivasi & .392 & .169 & & & .003 \\
\hline (Y1) & .351 & .158 & .314 & 2.324 & .002 \\
\hline $\begin{array}{l}\text { Prestas1 } \\
\text { Belajar } \\
\text { (Y2) }\end{array}$ & & & & & \\
\hline
\end{tabular}

Tabel 3: Ringkasan Pengaruh $\mathrm{X}$ terhadap Y1 dan Y2

Model Summary ${ }^{b}$

\begin{tabular}{|ll|l|}
\hline a. & Predictors: & $\begin{array}{l}\text { (Constant), Motivasi } \\
\text { Belajar (Y1), Prestasi } \\
\text { Belajar (Y2) }\end{array}$ \\
\hline b. & Dependent & $\begin{array}{l}\text { Pengelolaan Kelas } \\
(\mathrm{X})\end{array}$ \\
\hline
\end{tabular}

\section{PEMBAHASAN}

\section{Persepsi Responden terhadap Pengelolaan Kelas}

Persepsi atau tanggapan respon $\neg$ den terhadap pengelolaan kelas (variabel $\mathrm{X}$ ) oleh guru di SMP Negeri 2 Tambak diperoleh jawaban dengan kriteria sangat setuju sebesar $40,69 \%$, jawaban kriteria setuju 52,72\%, jawaban kriteria tidak setuju $6,60 \%$, dan kriteria sangat tidak setuju tidak ditemukan dalam jawaban atau $0 \%$, maka dari jumlah nilai rata-rata skor variabel X dapat dikemukakan bahwa tanggapan responden terhadap pengelolaan kelas oleh guru 52,72\% dengan nilai ratarata 3,34 dan pada kriteria setuju. Hal ini juga memberikan arti bahwa pengelolaan kelas dalam proses pembelajaran yang dilakukan oleh guru para siswa menyatakan setuju.

\section{Persepsi Responden terhadap Motivasi Belajar}

Persepsi responden terhadap motivasi belajar (variabel Y1) yang dilakukan oleh siswa SMP Negeri 2 Tambak diperoleh jawaban dengan kriteria sangat setuju 36,52\%, jawaban kriteria setuju 57,95\%, jawaban kriteria tidak setuju 5,52\%, dan kriteria sangat tidak setuju tidak ditemukan dalam jawaban atau 0\%, maka dari jumlah nilai rata-rata variabel motivasi belajar dapat dikemukakan bahwa siswa yang memiliki belajar $57,95 \%$ dengan nilai rata-rata 3,29 dan dengan kriteria setuju.

\section{Prestasi Belajar Siswa}

Prestasi belajar siswa (variabel Y2) yang dimaksud adalah nilai rata-rata dari Mapel Bahasa Indonesia, sehingga berda $\neg$ sarkan dokumen sekolah (2020) untuk nilai rata-rata Mapel tersebut diperoleh dari nilai ulangan harian, nilai ujian tengah semester, dan nilai ujian akhir semester, kemudian digabungkan dan jumlah serta dicari nilai rata-ratanya sehingga ditemukan nilai akhir sebagai prestasi belajar Mapel Bahasa Indonesia.

\begin{tabular}{|c|c|c|c|c|c|}
\hline Model & $\mathrm{R}$ & $\mathrm{R}$ Square & $\begin{array}{c}\text { Adjusted R } \\
\text { Square }\end{array}$ & $\begin{array}{c}\text { Std. Error of } \\
\text { the Estimate }\end{array}$ & $\begin{array}{c}\text { Durbin- } \\
\text { Watson }\end{array}$ \\
1 & $.344^{\mathrm{a}}$ & .118 & .729 & 5.35388 & 2.176 \\
& & & &
\end{tabular}

Dari 57 siswa sebagai responden diperoleh skor $=4.836$, kemudian dicari nilai rata-ratanya dengan membagi 57 siswa maka diperoleh nilai rata-rata $=$ 84,84. Nilai 84,84 ini jika diinterpretasikan dengan buku raport maka termasuk kriteria baik, sehingga dapat dikemukakan bahwa prestasi belajar yang dimiliki oleh siswa SMP Negeri 2 Tambak Kabupaten Banyumas adalah baik. 


\section{Pengaruh Pengelolaan Kelas terhadap Motivasi Belajar}

Pengaruh pengelolaan kelas terhadap motivasi belajar siswa diperoleh hasil beta standar 0,326 dengan signifikan 0,003. Angka 0,003 < 0,05, ini dapat diberikan penjelasan bahwa pengelolaan kelas memiliki pengaruh positif dan signifikan terhadap motivasi belajar siswa 0,326 atau 32,6\%. Hasil tersebut dapat dijabarkan pengelolaan kelas oleh guru mampu membangkitkan para siswa untuk belajar, maka siswa termotivasi untuk belajar secara maksimal. Hal tersebut dapat dikaitkan dimensi dan indikator yang mengkaji meliputi: 1) dimensi manajemen instruksional dengan indikator: (1) perencanaan dan pelaksanaan rutinitas pada proses pembelajaran; (2) perancangan kegiatan belajar untuk siswa; (3) pemilihan bahan pembelajaran yang baik dan tepat; dan (4) guru memantau dan menilai belajar serta kinerja akademik siswa dalam lingkungan belajar konstruktif; 2) dimensi perilaku meliputi indikator: (1) aturan yang membatasi siswa untuk tidak memiliki perilaku buruk; (2) pemberian penghargaan kepada siswa untuk berperilaku positif; dan (3) memotivasi siswa untuk menerima dan mematuhi aturan sekolah. Adapun motivasi belajar terkait kesadaran anak dalam belajar, maka dibutuhkan motivasi dari orang lain termasuk anggota keluarga, orang tua (ayah dan ibu). Hal tersebut menunjukkan adanya pengaruh dari pengelolaan kelas oleh guru terhadap motivasi belajar siswa.

Pengaruh ini didukung hasil hitung $\mathrm{F}=51,122$ pada signifikan 0,000 , karena $0,000<0,05$ Crobach Alpha (tabel 2), maka hipotesis yang diajukan: ada pengaruh positif dan signifikan pengelolaan kelas oleh guru terhadap motivasi belajar siswa SMP Negeri 2 Tambak diterima. Pengaruh tersebut didukung uji koefisian persamaan garis regresi yang diperoleh konstan (a) =
51,122 , sedangkan nilai $\mathrm{b}=0,326$ sehingga: $51,122+0,326 . \mathrm{Y} 1=$ 75,572 .

Koefisien b disebut sebagai koefisien arah regresi dan sebagai perubahan rata-rata variabel $X$ untuk setiap perubahan variabel Y1 sebesar satu unit. Hasil hitung tersebut dapat diterapkan bahwa setiap kali variabel X (pengelolaan kelas) bertambah satu, maka rata-rata variabel Y1 (motivasi belajar) juga bertambah 0,326. Dengan demikian tafsirnya sebesar 75,572 dan ini berarti bahwa besarnya nilai $t$ dapat dijadikan petunjuk untuk mengetahui ada tidaknya pengaruh pengelolaan kelas terhadap motivasi belajar siswa, dalam hal ini terdapat pengaruh secara positif $(+)$ sehingga hipotesis kerja: "ada pengaruh positif dan signifikan pengelolaan kelas oleh guru terhadap motivasi belajar siswa SMP Negeri 2 Tambak" diterima. Hal ini memberikan arti bahwa semakin baik pengelolaan kelas yang dilakukan oleh guru, maka akan semakin meningkat motivasi belajar yang dilakukan siswa SMP Negeri 2 Tambak. Hasil penelitian tersebut senada dengan penelitian pendahulu oleh Konstantina Koutrouba (2018) dengan judul: "Gaya Pengelolaan Kelas: Sebuah Persepsi Guru di Yunani.

Hasil penelitian menunjukkan bahwa ada 2 (dua) dimensi dalam pengelolaan kelas, yaitu dimensi manajemen instruksional dan manajemen perilaku dengan berbagai indikator yang mengupasnya. Sedang manajemen pembelajaran mengacu pada: 1) upaya guru untuk merencanakan dan melaksanakan rutinitas pengajaran seharihari; 2) merancang kegiatan belajar untuk siswa; 3) memilih bahan pembelajaran; dan 4) memantau dan menilai prosedur belajar dan kinerja akademik siswa dalam lingkungan belajar yang konstruktif. Adapun manajemen perilaku mengacu pada: 1) penetapan aturan yang menghalangi siswa untuk menampilkan perilaku buruk; 2) memberi 
penghargaan kepada siswa untuk perilaku positif; dan 3) memotivasi siswa untuk menerima serta memanfaatkan sepenuhnya aturan sekolah. Secara keseluruhan diperoleh kriteria sangat tinggi sehingga ke depan dapat dijadikan sebagai acuan pada penelitian dengan dimodifikasi variabel lain, seperti halnya yang peneliti lakukan.

\section{Pengaruh Pengelolaan Kelas terhadap Prestasi Belajar}

Pengaruh pengelolaan kelas terhadap prestasi belajar siswa diperoleh nilai beta standar 0,314 dengan signifikan 0,002. Angka $0,003<0,05$, ini memberikan arti bahwa pengelolaan kelas memiliki pengaruh positif dan signifikan terhadap prestasi belajar siswa 0,314 atau $31,4 \%$. Hasil ini dapat dijabarkan lebih mendalam bahwa pengelolaan kelas yang dilakukan guru mampu membangkitkan para siswa untuk belajar, sehingga prestasi belajar mengalami peningkatan. Hal tersebut bila dikaitkan dengan dimensi dan indikator yang mengkajinya pada pengelolaan kelas meliputi dimensi manajemen dan dimensi perilaku dengan berbagai indikator yang mengkajinya seperti yang dilakukan pada pembahasan di atas pada foint 4. Hal tersebut menunjukkan adanya pengaruh dari pengelolaan kelas oleh guru terhadap prestasi belajar siswa.

Pengaruh ini didukung hasil hitung $\mathrm{F}=51,122$ pada signifikan 0,000 , karena $0,000<0,05$ Crobach Alpha (tabel 2), maka hipotesis yang diajukan: ada pengaruh positif dan signifikan pengelolaan kelas oleh guru terhadap motivasi belajar siswa SMP Negeri 2 Tambak diterima. Pengaruh tersebut didukung uji koefisian persamaan garis regresi yang diperoleh konstan (a) = 51,122 , sedangkan nilai $\mathrm{b}=0,314$ sehingga: $51,122+0,314 \cdot \mathrm{Y} 2=77,184$

Koefisien b disebut sebagai koefisien arah regresi dan sebagai perubahan rata-rata variabel $X$ untuk setiap perubahan variabel Y2 sebesar satu unit. Hasil hitung tersebut dapat diterapkan bahwa setiap kali variabel X (pengelolaan kelas) bertambah satu, maka rata-rata variabel Y2 (prestasi belajar) juga bertambah 0,314. Dengan demikian tafsirnya sebesar 77,1842 dan ini berarti bahwa besarnya nilai $\mathrm{t}$ dapat dijadikan petunjuk untuk mengetahui ada tidaknya pengaruh pengelolaan kelas terhadap prestasi belajar siswa, karena pengaruh bertanda positif $(+)$ maka hipotesis kerja: "ada pengaruh positif dan signifikan pengelolaan kelas oleh guru terhadap prestasi belajar siswa SMP Negeri 2 Tambak" diterima. Hal ini memberikan gambaran bahwa semakin baik pengelolaan kelas yang dilakukan oleh guru, maka akan semakin meningkat prestasi belajar yang dicapai oleh siswa SMP Negeri Tambak 2 Kabupaten Banyumas. Hasil penelitian tersebut didukung hasil penelitian pendahulu oleh Rahmayanti (2015) dengan judul: "Pengaruh Pengelolaan kelas terhadap Peningkatan Prestasi Belajar Siswa". Hasil penelitian diperoleh simpulan bahwa ada pengruh positif dan signifikan pengelolaan kelas oleh guru terhadap prestasi belajar sebesar 0,661. Angka tersebut lebih besar dari tabel 0,213 dari subjek 85. Pengaruh positif, tersebut: 1) pembelajaran lebih efektif dan menarik; 2) dapat menjelaskan sesuatu yang sulit/ kompleks; 3) anak belajar dengan ulet; dan 4) meningkatkan tanggung jawab siswa.

\section{Pengaruh Pengelolaan Kelas terhadap Motivasi dan Prestasi Belajar}

Pengaruh pengelolaan kelas terhadap motivasi dan prestasi belajar siswa diperoleh skor beta standar: 0,326+ $0,314=0,64$. Kondisi ini menunjukkan bahwa pengelolaan kelas yang dilakukan guru berpengaruh positif dan signifikan terhadap motivasi dan prestasi belajar siswa, atau motivasi dan prestasi belajar siswa dipengaruhi oleh pengelolaan kelas 
guru. Hal tersebut dapat dijelaskan bahwa motivasi dan prestasi belajar dipengaruhi oleh kuatnya pengelolaan kelas oleh guru dengan berbagai dimensi dan indikator yang mengkajinya.

Berdasarkan hasil hitung menunjukkan adanya pengaruh positif dan signifikan pengelolaan kelas oleh guru terhadap motivasi dan prestasi belajar siswa, pengaruh ini didukung oleh hasil hitung $\mathrm{t}=4,9675$ pada signifikan 0,000 , karena $0,000<0,05$ Crobach Alpha, maka hipotesis yang diajukan: "ada pengaruh positif dan signifikan pengelolaan kelas oleh guru terhadap motivasi belajar dan prestasi belajar siswa SMP Negeri 2 Tambak" diterima. Pengaruh tersebut didukung uji koefisian persamaan garis regresi diperoleh nilai konstan (a) = 51,122 , sedangkan nilai $b=0,326+0,314$ $=0,64$.

Koefisien b disebut sebagai koefisien arah regresi dan sebagai perubahan rata-rata variabel $X$ untuk setiap perubahan variabel Y1 dan Y2 sebesar satu unit. Hasil hitung tersebut dapat diterapkan bahwa setiap kali variabel $\mathrm{X}$ (pengelolaan kelas oleh guru) bertambah satu, maka rata-rata variabel Y1 (motivasi belajar) dan variabel Y2 (prestasi belajar) juga bertambah 0,64. Dengan demikian tafsirnya sebesar 0,64 , ini berarti bahwa besarnya nilai $\mathrm{t}$ dapat dijadikan petunjuk untuk mengetahui ada tidaknya pengaruh pengelolaan kelas guru terhadap motivasi dan prestasi belajar siswa. Pengaruh ini bertanda positif (+), maka hipotesis kerja: "ada pengaruh positif dan signifikan pengelolaan kelas oleh guru terhadap motivasi dan prestasi belajar siswa SMP Negeri 2 Tambak" diterima. Hal ini memberikan gambaran bahwa semakin baik pengelolaan kelas oleh guru maka akan semakin meningkat motivasi belajar yang dimiliki oleh siswa dan prestasi belajar yang dicapai oleh siswa juga mengalami peningkatan. Hasil penelitian tersebut senada dengan penelitian pendahulu oleh Risnawita (2009) dengan judul: "Hubungan Pengelolaan Kelas dengan Hasil Belajar: Studi Metaanalis". Hasil penelitian menerima hipotesis yang diajukan, karena hasilnya diperoleh simpulan ada hubungan antara proses pembelajaran dalam pengeloaan kelas dengan hasil belajar dapat diterima. Hal ini berarti bahwa pengelolaan kelas yang baik memiliki beberapa keuntungan: 1) penambahan akses untuk belajar; 2) penambahan sumber informasi lebih baik; 3) penambahan ketersediaan media alternatif untuk mengakomodasi strategi pembelajaran yang beranekaragam; dan 4) motivasi belajar semakin tinggi, baik model pembelajaran individu maupun kelompok menjadi lebih potensial. Selain itu juga didukung hasil penelitian Suprihatin (2015) dengan judul: "Upaya Guru dalam Meningkatkan Motivasi Belajar Siswa”. Hasil penelitian merekomendasikan bahwa proses pembelajaran akan berhasil mana kala siswa mempunyai motivasi dalam belajar, maka guru perlu menumbuhkan motivasi belajar siswa. Guna memperoleh hasil belajar yang optimal, guru dituntut kreatif membangkitkan motivasi belajar siswa, karena dengan guru kratif menjadikan siswa tergugah dalam pembelajaran yang akan dialami siswa atau siswa yang sedang mengikuti proses pembelajaran.

\section{PENUTUP}

Simpulan penelitian guna menjawab rumusan masalah dan sebagai pencapaian tujuan penelitian adalah: 1) pengelolaan kelas oleh guru diperoleh kriteria setuju dengan skor $52,72 \%$; 2) motivasi belajar untuk siswa diperoleh kriteria setuju dengan 52,72\%; 3) prestasi belajar Mapel Bahasa Indonesia diperoleh kriteria baik dengan nilai rata-rata 84,84 ; 4) terdapat pengaruh positif dan signifikan pengelolaan kelas oleh guru terhadap motivasi belajar siswa SMP Negeri 2 
Tambak. Pengaruh tersebut ditunjukkan nilai koefisien sebesar 0,326 atau $32,6 \%$, yang berarti sisanya $67,4 \%$ dipengaruhi oleh faktor lain selain variabel yang digunakan dalam penelitian ini; 5) terdapat pengaruh positif dan signifikan pengeloaan kelas oleh guru terhadap prestasi belajar siswa SMP Negeri 2 Tambak. Pengaruh tersebut ditunjukkan nilai koefisien sebesar 0,314 atau $31,4 \%$, hal ini berarti sisanya $68,6 \%$ dipengaruhi oleh faktor lain selain variabel yang digunakan dalam penelitian ini; dan 6) variabel yang terpengaruh oleh pengelolaan kelas guru adalah variabel motivasi belajar siswa. Hal itu dapat dikemukakan sebab pengaruh pengelolaan kelas terhadap motivasi belajar siswa diperoleh skor $0,326>0,314$ dari pengaruh pengelolaan kelas terhadap prestasi belajar siswa.

Berdasarkan simpulan yang diperoleh, saran sebagai bahan rekomendasi diberikan untuk: 1) bagi Kepala sekolah, dapat digunakan sebagai bahan masukan untuk menentukan langkah dan kebijakan terkait dukungan pelaksanaan pembelajaran berupa pengadaan sarana dan prasarana, agar siswa memiliki motivasi belajar yang berakibat pada peningkatan prestasi belajar, salah satu dapat dibicarakan kepada orang tua/wali murid ketika ada pertemuan seperti dalam pengambilan raport; 2) bagi guru, hasil penelitian ini dapat memberikan masukan bagi guru untuk meningkatkan proses pembelajaran dengan menggunakan metode dan media yang disesuaikan dengan materi, sehingga model pembelajaran tidak monoton dan konvensional seperti halnya metode ceramah dan tanya jawab yang kurang memberi motivasi kepada siswa untuk belajar; 3) bagi peserta didik, dapat memberikan informasi kepada anak, sehingga akan termotivasi untuk meningkatkan minat dan motivasi belajar yang berujung pada peningkatan prestasi belajar; dan 4) bagi peneliti mendatang, dapat memberikan informasi baru, sehingga peneliti berikutnya dapat memodifikasi dengan variabel lain selain variabel pengelolaan kelas, motivasi, dan prestasi belajar dan akhirnya ditemukan teori baru yang mendukung dan menambah khasanah teori yang ada, khususnya terkait dengan kajian Sumber Daya Manusia (SDM) Pendidikan.

Asumsi dan keterbatasan pengembangan penelitian ini: 1) penelitian hanya terbatas pada siswa kelas VIII di SMP Negeri 2 Tambak Kabupeten Banyumas; dan 2) penelitian hanya membuktikan pengaruh pengelolaan kelas oleh guru, motivasi belajar, dan prestasi belajar mata pelajaran Bahasa Indonesia di SMP Negeri 2 Tambak Kabupeten Banyumas pada semester gasal tahun pelajaran 2019/2020.

\section{DAFTAR PUSTAKA}

Arikunto. Suharsimi, 2012, Prosedur Penelitian: Suatu Pendekatan Praktik, Jakarta: Rineka Cipta.

Bakar, Rambi. 2014, "The Effect of Learning Motivation on Student's Productive Competencies in Vocational High School, West Sumatra". International Journal of Asian Social Science.ISSN(e): 2224-4441/ISSN(p): 2226-5139.

Davis, Keith \& John W. Newstrom, 2012, Perilaku dalam

Pembelajaran, Terjemahan: Daniel Lukito. Jakarta: Erlangga.

Ghozali. Imam, 2012, Aplikasi Analisis Multivariat dengan Program SPSS. Semarang: Badan Penerbitan Universitas Diponegoro.

Koutrouba, Konstantina. 2018, "Classroom Management Style: Greek Teachers' Perceptions", International Journal of 
Instruction, October 2018, Vol.11, No.4, e-ISSN: 1308-1470, www.eiji.net p-ISSN: 1694-609X.

Makmun. Abin Syamsudin, 2011, Psikologi Kependidikan. Bandung: Rosdakarya.

Mudzakir. Achmad, 2012, Pembinaan Kepribadian Anak, Jakarta: Medco Energi Internasional tbk.

Nasution, S., 2011, Ilmu Pendidikan:

Teoretis dan Praktis,, Bandung: Tarsio.

Sardiman S. Arief, 2012, Media Pendidikan: Pengertian, Pengembangan, dan Pemanfaatannya, Jakarta: Raja Grafindo Persada
Setiaji. Bambang, 2012, Penelitian Kuantitatif, Surakarta: UMS Press.

Simamora S., 2010, Teknologi Masa Kini, Penerjemah: Erly Suandy. Jakarta: Salemba Empat.

Sinduwinata, 2012, Pemanfaatan dan Penggunaan Media, Bandung: Alfabeta.

Strees. George dan Sayles. R. Leonard, 2010, Personal-The Human Problems of Management, Penerjemah: Hadikusumo, M. Grace dan Hamyah, Rochmulyati, Jakarta: Teruna Grafica.

Usman. Khaerul, 2010, Perilaku Organisasi, Bandung: Pustaka Setia. 